\title{
Tetrapisispora phaffii killer toxin is a highly specific $\beta$-glucanase that disrupts the integrity of the yeast cell wall Francesca Comitini ${ }^{1}$, Ilaria Mannazzu ${ }^{1,2}$ and Maurizio Ciani*1
}

\author{
Address: ${ }^{1}$ Dipartimento SAIFET, Sez Microbiologia Alimentare, Industriale e Ambientale, Università Politecnica delle Marche, Via Brecce Bianche, \\ 60131 Ancona, Italy and ${ }^{2}$ Current address: Dipartimento di Scienze Ambientali Agrarie e Biotecnologie Agro-Alimentari, Università degli Studi di \\ Sassari; Via de Nicola n 2, 07100 Sassari, Italy \\ Email: Francesca Comitini - f.comitini@univpm.it; Ilaria Mannazzu - i.mannazzu@uniss.it; Maurizio Ciani* - m.ciani@univpm.it \\ * Corresponding author
}

Published: 27 October 2009

Microbial Cell Factories 2009, 8:55 doi:10.1 186/1475-2859-8-55
Received: 14 September 2009

Accepted: 27 October 2009

This article is available from: http://www.microbialcellfactories.com/content/8///55

(C) 2009 Comitini et al; licensee BioMed Central Ltd.

This is an Open Access article distributed under the terms of the Creative Commons Attribution License (http://creativecommons.org/licenses/by/2.0), which permits unrestricted use, distribution, and reproduction in any medium, provided the original work is properly cited.

\begin{abstract}
Background: Killer yeasts have been used to combat contaminating wild yeasts in food, to control pathogenic fungi in plants, and in the medical field, to develop novel antimycotics for the treatment of human and animal fungal infections. Among these killer yeasts, Tetrapisispora phaffii (formerly known as Kluyveromyces phaffii) secretes a glycoprotein known as Kpkt that is lethal to spoilage yeasts under winemaking conditions. In the present study, the mode of action of Kpkt, and the specific damage produced by this toxin on sensitive yeasts is investigated.

Results: The use of castanospermine, a $\beta$-glucanase inhibitor, demonstrated that $\beta$-glucanase activity is essential for the Kpkt killer activity in vivo. Accordingly, Kpkt has no killer activity on either sensitive yeast spheroplasts or whole sensitive cells in the presence of isosmothic medium ( 0.8 molar sorbitol). Kpkt induces ultrastructural modifications in the cell wall of sensitive strains, as shown by confocal microscopy, laser-scanning electron microscopy, and atomic force microscopy. The Kpkt killer action is mediated by the glucidic portion of the toxin. This, in turn, appears to be involved both in the stronger cytocidal activity and in the selectivity for the sensitive strain shown by Kpkt compared to laminarinase.
\end{abstract}

Conclusion: Collectively, these data indicate that the mode of action of Kpt is directed towards the disruption of cell-wall integrity, and that this is mediated by a highly specific $\beta$-glucanase activity. In this, Kpkt differs from other microbial $\beta$-glucanases that do not show killer activities.

\section{Background}

Investigations into the killer phenomenon in yeast have resulted in substantial progress towards elucidation of the intricacies of this phenomenon. In addition, they have provided valuable insights into a number of fundamental aspects of eukaryotic cell biology and virus-host-cell interactions [1-3].
Killer toxins act on sensitive cells through various mechanisms, such as inhibition of DNA replication [1], induction of membrane permeability changes [4], and arrest of the cell cycle in G1 phase. Moreover, in some cases, a toxin can interfere with cell-wall synthesis by inhibiting $\beta$ 1,3-glucan synthase [5] or by hydrolyzing the major cellwall components, $\beta-1,3$ glucans and 1,6 glucans [6-8]. 
To date, it is known that under competitive conditions, the killer phenomenon offers a considerable advantage to these yeast strains against other sensitive microbial cells in their ecological niches. This advantage has a basic and applied significance, and killer yeasts and their toxins have found several applications. Indeed, killer yeasts have been used to combat contaminating wild yeasts in food, and to control pathogenic fungi in plants [9-11]. In the medical field, these yeasts have been used in the development of novel antimycotics for the treatment of human and animal fungal infections $[1,12,13]$ and in the biotyping of pathogenic yeasts and yeast-like fungi [14-16]. Moreover, killer yeasts have been used to control contaminating wild-type yeasts in the winemaking and fermentation industries. In particular, the Kluyveromyces phaffii (recently reclassified as Tetrapisispora phaffii) [17] killer toxin, known as Kpkt and known to be active in the winemaking environment, has shown a wide cytocidal spectrum towards apiculate and other spoilage yeasts [18].

Kpkt is a glycoprotein with a molecular mass of $33 \mathrm{kDa}$. Its $\mathrm{NH}_{2}$-terminal region shows $93 \%$ identity to $\beta$-1,3-glucanase of $S$. cerevisiae, and $80 \%$ identity to $\beta$-1,3-glucan transferase of Candida albicans [6]. These two proteins are involved in connecting newly synthesized $\beta$-1,3-glucan chains to existing chains, and in linking them through the $\beta-1,6$-linkage $[1,19,20]$. Moreover, Kpkt shows $\beta$-glucanase activity in vitro [6], like the NCYC 434 killer toxin of Pichia anomala $[7,21]$.

In the present study, to gain further information into the mechanism of action of Kpkt, we have evaluated the effects of this toxin on the ultrastructure of the cell wall of a sensitive target, and the relationship between $\beta$-glucanase and killer activities in vivo.

\section{Methods}

\section{Yeast strains and media}

The DBVPG 6706 Tetrapisispora phaffii and NCYC 232 S. cerevisiae (DBVPG 6497) used as yeast killer strains were obtained from the Industrial Yeast Collection of the University of Perugia (DBVPG). The DBVPG 6500 S. cerevisiae strain was used as the sensitive strain, and the $\mathrm{BC}$ commercial dried yeast strain (Lallemand Inc.) was used as the non-sensitive strain. All yeast cultures were grown in YPD medium containing $20 \mathrm{~g} \mathrm{l}^{-1}$ glucose, $20 \mathrm{~g} \mathrm{l}^{-1}$ peptone and $10 \mathrm{~g} \mathrm{l}^{-1}$ yeast extract. The medium for the killer activity assay was as follows: $45 \mathrm{~g} \mathrm{l}^{-1}$ malt agar (Difco) and 0.15 $\mathrm{mg} \mathrm{l}^{-1}$ methylene blue, adjusted to $\mathrm{pH} 4.6$ with 0.1 molar citrate phosphate buffer.

\section{Enzymatic activity inhibition in the presence of castanospermine}

Kpkt was purified as already described [6] and to determine whether its activity was sensitive to the $\beta$-glucanase inhibitor castanospermine, $25 \mu \mathrm{g}$ of Kpkt in $0.5 \mathrm{ml}$ citrate phosphate buffer ( $\mathrm{pH} 4.5$ ) was mixed with $0.5 \mathrm{ml} 25 \mu \mathrm{M}$ castanospermine (Sigma-Aldrich, Milan) and incubated at $25^{\circ} \mathrm{C}$ for $1 \mathrm{~h}$ under static conditions. $\beta$-glucanase activity was measured, as described previously [6]. The killer activity was determined using a well-test assay [6] and viable plate counts. Briefly: DBVPG 6500 sensitive strain $\left(10^{5}\right.$ cells $\mathrm{ml}^{-1}$ ) growing in exponential phase was added to the mixture of Kpkt and castanospermine and incubated at $25^{\circ} \mathrm{C}$ for $24 \mathrm{~h}$. After this, the cells were harvested by centrifugation $\left(400 \times g\right.$ for $1 \mathrm{~min}$ at $\left.4^{\circ} \mathrm{C}\right)$, washed twice with sterile water, and plated on YPD.

\section{Kpkt effect on spheroplasts and whole cells in presence of isosmothic medium}

The Kpkt killer activity was determined on sensitive yeasts, to verify the involvement of receptor sites in the killer activity. $2 \times 10^{6}$ cells $\mathrm{ml}^{-1}$ sensitive yeast spheroplasts prepared as described by Komiyama et al. [22] were incubated at each time ( 24 and $36 \mathrm{~h}$ ) at $25^{\circ} \mathrm{C}$, without and with $25 \mu \mathrm{g}$ of purified Kpkt in the YPD buffered medium, supplemented with 0.8 molar sorbitol, as osmotic stabilizer. The spheroplasts were washed three times in 0.8 molar sorbitol buffer and then used for the experimental trials. Spheroplasts were stained with $0.5 \%$ methylene blue dissolved in $50 \mathrm{mM} \mathrm{KH} \mathrm{PO}_{4}-\mathrm{Na}_{2} \mathrm{HPO}_{4}(\mathrm{pH} 4.5)$ containing 0.8 molar sorbitol and their death was monitored by light microscopy using a Thoma-Zeiss counting chamber. At the time defined for the spheroplasts counting, aliquots of spheroplast suspensions were subjected to flow-cytometry analyses as described by Comitini et al. [6] to establish the ratio between live and dead cells following the Kpkt treatments. The positive control was obtained adding an equal amount of Kpkt, inactivated by boiling for 15 minutes, to sensitive spheroplasts. Kpkt activity was also assayed on whole sensitive cells at $25^{\circ} \mathrm{C}$ with $25 \mu \mathrm{g}$ of purified toxin in 0.1 molar of citrate-phosphate buffer (pH 4.5) in presence or absence of 0.8 molar sorbitol, as osmotic stabilizer. The mortality was evaluated using viable plate counts and methylene blue stained cells in a Thoma-Zeiss counting chamber after $48 \mathrm{~h}$ of incubation.

\section{Cell-wall damage}

Sensitive yeast growing exponentially at $25^{\circ} \mathrm{C}$ for $18 \mathrm{~h}$ $\left(10^{5} \mathrm{cell} \mathrm{ml}^{-1}\right)$ were mixed with 46 aU of Kpkt $\left(0.1 \mathrm{mg} \mathrm{ml}^{-}\right.$ 1) in citrate phosphate buffer, pH 4.6 ( $\varnothing$ halo $11.0 \mathrm{~mm})$, and incubated for $24 \mathrm{~h}$ at $25^{\circ} \mathrm{C}$. To compare Kpkt with another well known killer toxin, the $S$. cerevisiae K1 toxin was used after a partial purification carried out as follows. K1 killer strain was 48-h cultured and supernatant was filter-sterilized and then 30-fold concentrated with AmiconYM10 (10-kDa cut-off membrane; Pharmacia, Uppsala, Sweden). Concentrated K1 toxin was dialysed with $10 \mathrm{mM}$ citrate phosphate buffer, $\mathrm{pH} 4.6$ using dialysis membrane (12 kDa, Medicell, Int. Ltd, London). The 
killer activity of partially purified $\mathrm{K} 1$ was evaluated by well test carried out at $25^{\circ} \mathrm{C}$ in malt agar medium buffered at pH 4.6 with 0.1 molar citrate-phosphate buffer and inoculated with the sensitive strain DBVPG 6500. In these conditions $\mathrm{K} 1$ produced a diameter of halo of $11 \mathrm{~mm}$, comparable to that of the purified Kpkt (46 aU).

Different cell-wall damage with the sensitive yeast was obtained by boiling cells for $10 \mathrm{~min}$, or treating them with $70 \%$ ethanol or $2 \mathrm{mg} \mathrm{ml}^{-1}$ Zymolyase $^{\circledast}$ (ICN, Biomedicals Inc., UK). After these incubations, the cells were collected by centrifugation, washed two times in sterile water, resuspended in $30 \mu \mathrm{l} 2 \mu \mathrm{M}$ solution of Calcofluor White Stain (Sigma-Aldrich, Milan) and observed under a fluorescence microscope (Biorad, MRC $1024 \mathrm{UV}$ ) provided with an ebq 100 isolated lamp, a UV filter, and $25 \times$ and $100 \times$ objectives.

The potential damage to the envelope of sensitive cells resulting from Kpkt treatment was also investigated by scanning electron microscopy (SEM). Initially, sensitive cells grown overnight were counted using a Thoma-Zeiss chamber, and $10^{5}$ cell ml-1 were incubated at $25^{\circ} \mathrm{C}$ for 24 $\mathrm{h}$ without and with purified Kpkt ( $\varnothing$ halo $11.0 \mathrm{~mm}$ ). After incubation, the cells were harvested by centrifugation, washed in sterile water and progressively dehydrated by successive soaking in $10 \%, 30 \%, 50 \%, 70 \%, 80 \%, 90 \%$, $95 \%$ and $100 \%$ ethanol. Soaking in isopentyl acetate was performed before they were critical point dried in $\mathrm{CO}_{2}$ using a Polaron CPD 7501. For each sample, the filters were then attached to the large scanning microscopy stubs and coated with gold-palladium by cathode spreading in a Polaron Sputter Coater. Sample observation was performed using a Philips XL20 SEM operating at a voltage of $10 \mathrm{kV}$ to $20 \mathrm{kV}$.

To confirm the damage produced by Kpkt on the cell wall of sensitive cells, and to examine it in more detail, the samples previously observed by SEM were used for an atomic force microscopy (AFM) study. Briefly, $10 \mu \mathrm{l}$ of $2 \times$ $10^{6}$ cells were collected from each sample, applied to a Corning microscope slide, and observed by AFM. The images were analysed using the BG-one software.

\section{$\beta$-glucanase and Kpkt enzymatic activity}

The effects of increasing concentrations of laminarinase were studied in both the sensitive and the non-sensitive yeast strains, by evaluation of the threshold values at which the hydrolytic enzyme is lethal for yeast cells. Laminarinase (Sigma-Aldrich) was used at concentrations of $0.05,2.5,12.5$, and $25 \mathrm{mg} \mathrm{ml}^{-1}(0.25,12.5,62.5,125 \mathrm{IU})$ in a final volume of $1 \mathrm{ml}$ in $50 \mathrm{mM}$ sodium acetate buffer (pH 4.5). Suspensions of both sensitive and non-sensitive cells $\left(10^{6} \mathrm{cell} \mathrm{ml}^{-1}\right)$ were added to each hydrolytic enzyme concentration and incubated for $24 \mathrm{~h}$ at $37^{\circ} \mathrm{C}$. After this time, the viability of the yeast cells was analysed by viable plate counting and by flow cytometry upon propidium iodide staining. A positive control was added with yeast cells not treated with laminarinase.

\section{Effects of endoglycosidase-H on Kpkt killer activity} KpKt was treated with endoglycosidase H (45 IU [mg protein $]^{-1}$; ICN Biomedicals) and the killer activity of the residual protein portion of Kpkt was determined. The assays were performed following the procedure described by Elgersma et al. [23], modified as follows: $2 \mu$ l endogly-

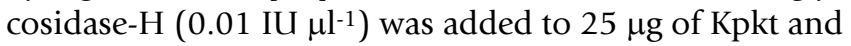
$73 \mu \mathrm{l}$ buffer ( $150 \mathrm{mM}$ sodium citrate, $1 \mathrm{mM}$ PMSF, $10 \mu \mathrm{M}$ pepstatin, $5 \mathrm{mM}$ sodium azide, $\mathrm{pH}$ 5.9). A positive control with heat-inactivated Kpkt was prepared. A negative control was prepared by mixing $25 \mu \mathrm{g}$ of Kpkt with $75 \mu \mathrm{l}$ buffer in the absence of the lytic enzyme.

All of the samples were incubated at $28^{\circ} \mathrm{C}$ for $20 \mathrm{~h}$ and 48 h. After this, the mixtures were added to the sensitive cells $\left(2 \times 10^{5}\right.$ cells $\left.\mathrm{ml}^{-1}\right)$ and than subjected to viable plate counts and the well test to assess killer activity.

\section{Results \\ Castanospermine inhibits Kpkt killer action}

While the $\beta$-glucanase activity of Kpkt has already been demonstrated in vitro [6], its involvement in Kpkt killer action was here assessed in vivo in the presence of castanospermine, a specific $\beta$-glucanase inhibitor. As shown in Table 1 , at $25 \mu \mathrm{M}$ castanospermine, there was a dramatic reduction in the glucanase activity, which was associated with a complete loss of Kpkt killer activity, confirming a

Table I: Effects of the $\beta$-glucanase inhibitor castanospermine on Kpkt killer activity.

\begin{tabular}{|c|c|c|c|}
\hline Purified Kpkt & $\begin{array}{c}\text { Enzymatic activity } \\
\left(\mathrm{g} \mathrm{l}^{-1} \text { glucose }\right)\end{array}$ & $\begin{array}{c}\text { Killer activity } \\
\varnothing \text { halo in well test } \\
(\mathrm{mm})\end{array}$ & $\begin{array}{c}\text { Viable cell counts } \\
\text { CFU ml-1 } \\
\text { (sensitive cells) }\end{array}$ \\
\hline No castanospermine & 0.032 & 11.0 & $0.5 \times 10^{2}$ \\
\hline $25 \mu \mathrm{M}$ castanospermine & 0.0001 & 0.0 & $1.5 \times 10^{5}$ \\
\hline
\end{tabular}

The Kpkt treatment was carried out with $25 \mu \mathrm{g}$ toxin for $24 \mathrm{~h}$ at $25^{\circ} \mathrm{C}$. The initial inoculum of the sensitive strain was $10^{5}$ cell $\mathrm{ml}^{-1}$. Growth of the sensitive cells was measured through viable plate counts. 
Table 2: Effect of Kpkt on spheroplasts

\begin{tabular}{ll}
\hline Trial & \% dead cells \\
\hline Spheroplasts + heat treated Kpkt & $0.29 \pm 0.23$ \\
Spheroplasts + Kpkt & $1.39 \pm 0.42$ \\
Whole cells + Kpkt & $98.5 \pm 0.77$ \\
\hline
\end{tabular}

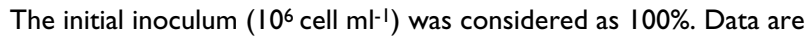
means $\pm \mathrm{SD}$ of three experiments.

direct relationship between its $\beta$-glucanase and killer activities.

\section{The cell wall is the target of Kpkt}

To further elucidate the mechanism of action of Kpkt, its killer activity was investigated with spheroplasts of sensitive cells. Figure 1 shows the results of flow cytometry of propidium-iodide-stained spheroplasts after Kpkt treatment. It is known that propidium iodide stains the nucleic acids of dead or damaged cells, providing an indirect measure of cell membrane integrity [24]. Spheroplasts of the sensitive strain treated with inactivated and active Kpkt (Figures 1a, b, respectively) showed the same profiles of propidium iodide fluorescence, indicating that in contrast to whole sensitive cells, spheroplasts are resistant to this toxin (Figure 1c). These results were confirmed with viable plate counts (Table 2). The evaluation of Kpkt activity on whole sensitive cells in the presence of 0.8 molar sorbitol as an osmotic stabilizer, confirmed that its zymocidal action is directed towards the cell wall (Table $3)$. Indeed, whole sensitive cells treated with Kpkt survived in an isosmothic environment, while they died without an osmotic stabilizer.

Calcofluor White ${ }^{\circledR}$ Stain selectively links chitin in the cell wall and allows the observation of changes in envelope morphology. This was used to investigate the effects of Kpkt on the cell wall, and to provide further information on its mode of action. As shown in Figure 2, untreated and viable sensitive yeast cells showed a uniform and homogenous shape, with a continuous perimeter and fluorescence localized mainly to the bud scars (Figure 2a). Ethanol treatment damaged the cell membrane but not the cell wall, which maintained the same aspect as for untreated and viable cells, with fluorescence localized to the bud scars (Figure 2c). In contrast, the fluorescence was not well localized when the cells were killed at $100^{\circ} \mathrm{C}$, indicating the complete disintegration of the cell wall (Figure 2d). Sensitive cells treated with Zymoliase ${ }^{\circledR}$, a $\beta$ 1,3-glucan laminarin-penta-hydrolase that lyses yeast cell walls, showed a discontinuous cell perimeter (Figure 2b). Upon Kpkt treatment, the cell wall was characterized by diffuse fluorescence, indicating the effective damage by Kpkt to the envelop of the sensitive strain (Figure 2e). However, treatment of the sensitive cells with the K1 killer toxin (Figure 2f), the mode of action of which is directed towards the cell membrane, did not show any modifications of the cell-wall structure.

\section{Kpkt affects cell-wall ultrastructure}

The effects of Kpkt on the cell wall of sensitive cells were investigated by scanning electron microscopy (SEM) and atomic force microscopy (AFM). SEM analysis showed that after Kpkt treatment, the sensitive cells have a rough surface and an irregular and uneven shape (Figure 3). SEM specimens are coated with a film of evaporated gold that is approximately $20 \mathrm{~nm}$ thick, and this application might mask possible ultra-structural changes in the envelope $[25,26]$. Thus, to analyze the ultra-structural modifications produced by Kpkt in more detail, AFM was used.

With AFM, the cells were visualized at a very high resolution, both uncoated and alive, producing excellent images that allowed semi-quantitative studies of the roughness of the envelope of the sensitive yeasts. AFM analysis indicated that the average roughness of the untreated cells was very different to that of the samples treated with Kpkt. While the untreated cells and K1-treated cells showed similar roughness (4.39 and $4.88 \mathrm{~nm}$, respectively), the cell surface of the Kpkt-treated cells appeared irregular, showing a high level of roughness $(248.27 \mathrm{~nm})$, with a high mean value. Moreover, the high entropy level, which quantifies the information concerning the random events in the system, highlighted a higher level of abnormality in the Kpkt-treated sensitive cells (8.146) compared with untreated cells (7.174) and K1-treated cells (6.347) (adimensional parameter). The images from AFM confirmed the results obtained by SEM (Figure 4).

Table 3: Kpkt activity in the presence and absence of sorbitol as an osmotic stabilizer

\begin{tabular}{ccc}
\hline Medium & \% Dead cells ${ }^{\mathbf{a}}$ \\
\hline & Thoma-Zeiss counting chamber & Viable cell counts After $48 \mathrm{~h}$ \\
Whole sensitive cells + Kpkt & $5.4 \pm 1.0$ & $4.0 \pm 0.8$ \\
in 0.8 molar sorbitol & $55.4 \pm 5.2$ & $93.9 \pm 3.0$ \\
Whole sensitive cells + Kpkt & & \\
\hline
\end{tabular}

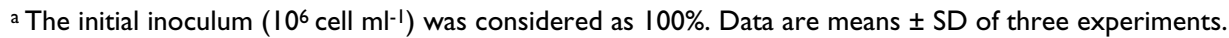




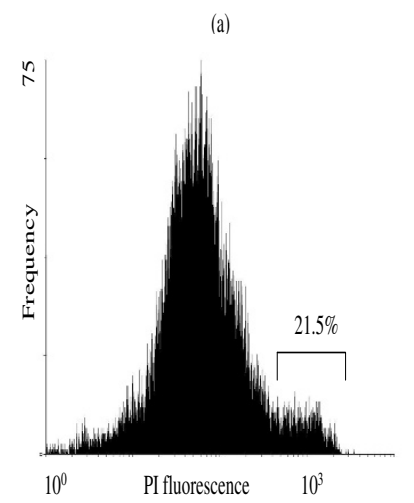

(b)

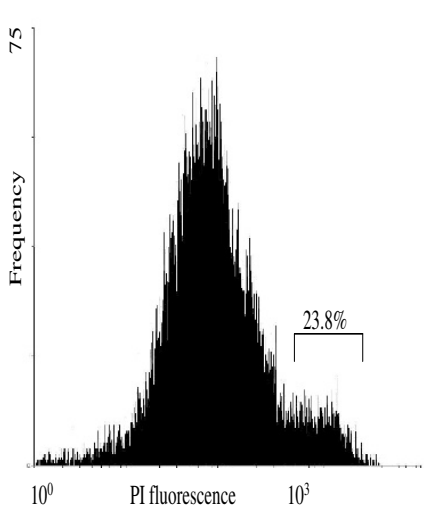

(c) $86.8 \%$

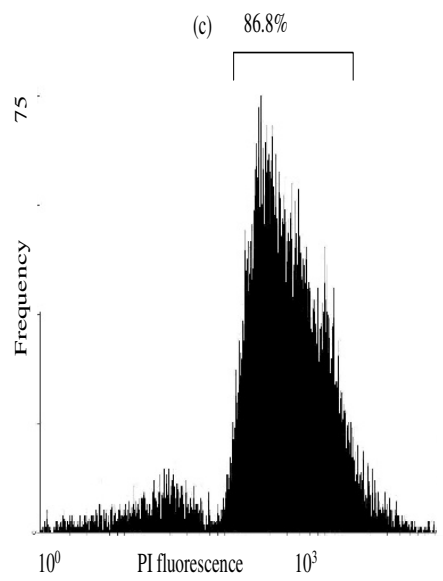

\section{Figure I}

Flow cytometry analysis of the sensitive strain. $10^{6}$ cells $\mathrm{ml}^{-1}$ treated with $25 \mu \mathrm{g} \mathrm{Kpt}$ for $24 \mathrm{~h}$ at $20^{\circ} \mathrm{C}$, showing propidium iodide stained DBVPG 6500: (a) spheroplasts with heat-inactivated Kpkt; (b) spheroplast with Kpkt; and (c) sensitive whole cells with Kpkt. The peak on the left on the $x$ axis is made up of viable spheroplasts/cell (not permeable to propidium iodide). The peak on the right of the $x$ axis is made up of dead spheroplasts/cells (permeable to propidium iodide). Percentages represent the mortality after flow-cytometry analyses. 
(a)

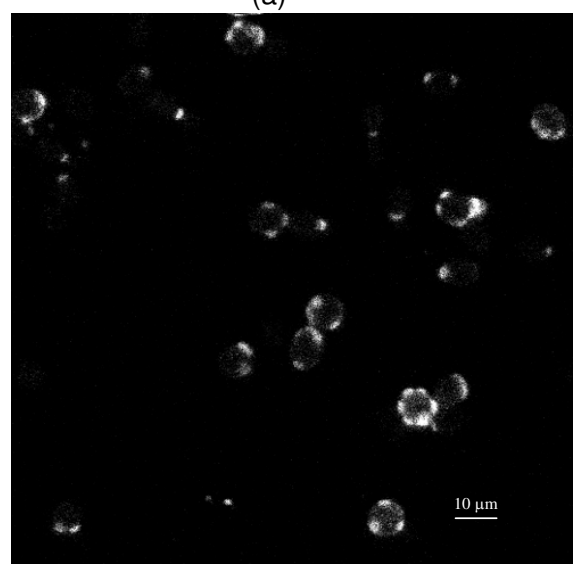

(c)

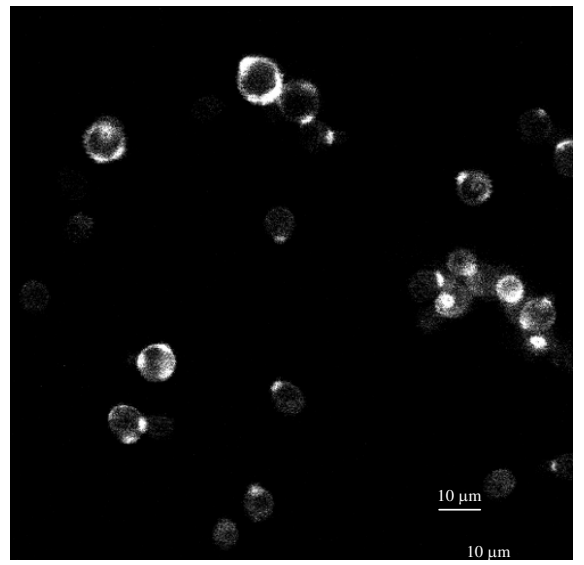

(e)

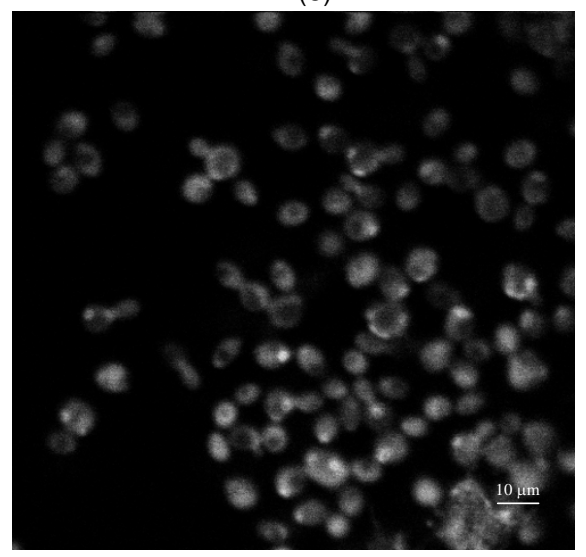

(b)

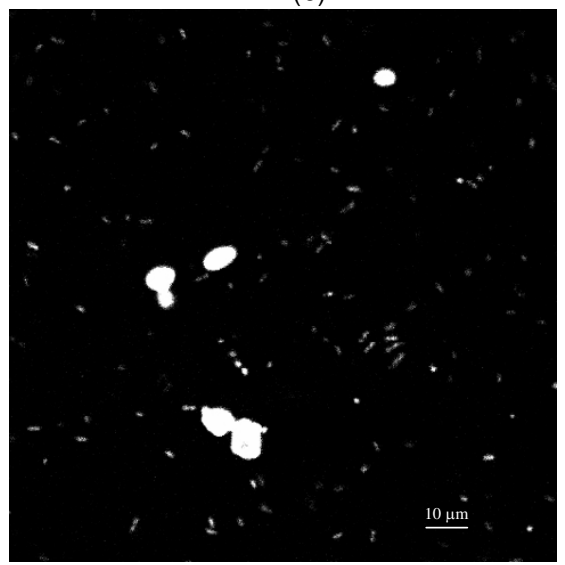

(d)

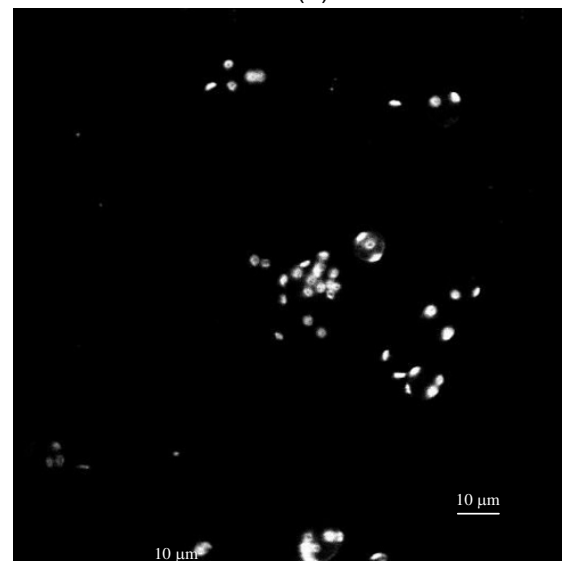

(f)

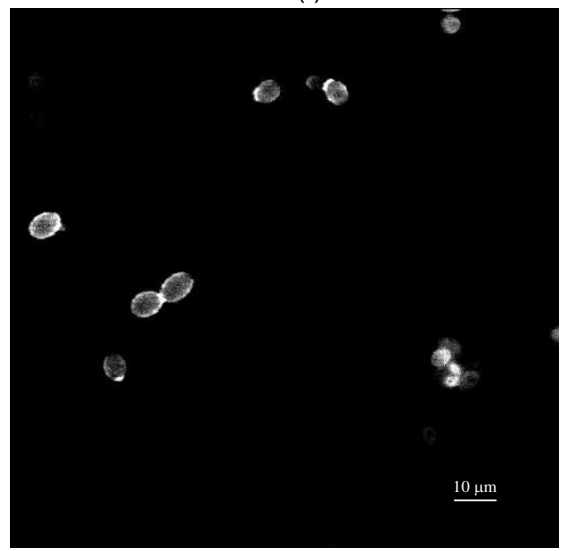

Figure 2

Calcofluor White ${ }^{\circledR}$ staining for cell-wall damage. (a) untreated cells; (b) cells heat treated at $100^{\circ} \mathrm{C}$ for 10 min; (c) cells treated with $70 \%$ ethanol for $3 \mathrm{~h}$; (d) cells broken after treatment for $2 \mathrm{~h}$ at $37^{\circ} \mathrm{C}$ with $0.02 \mathrm{Ul}$ of zymolyase; (e) cells treated for $24 \mathrm{~h}$ with $50 \mu \mathrm{g}$ purified Kpkt; and (f) cells treated for $24 \mathrm{~h}$ with partially purified KI. 

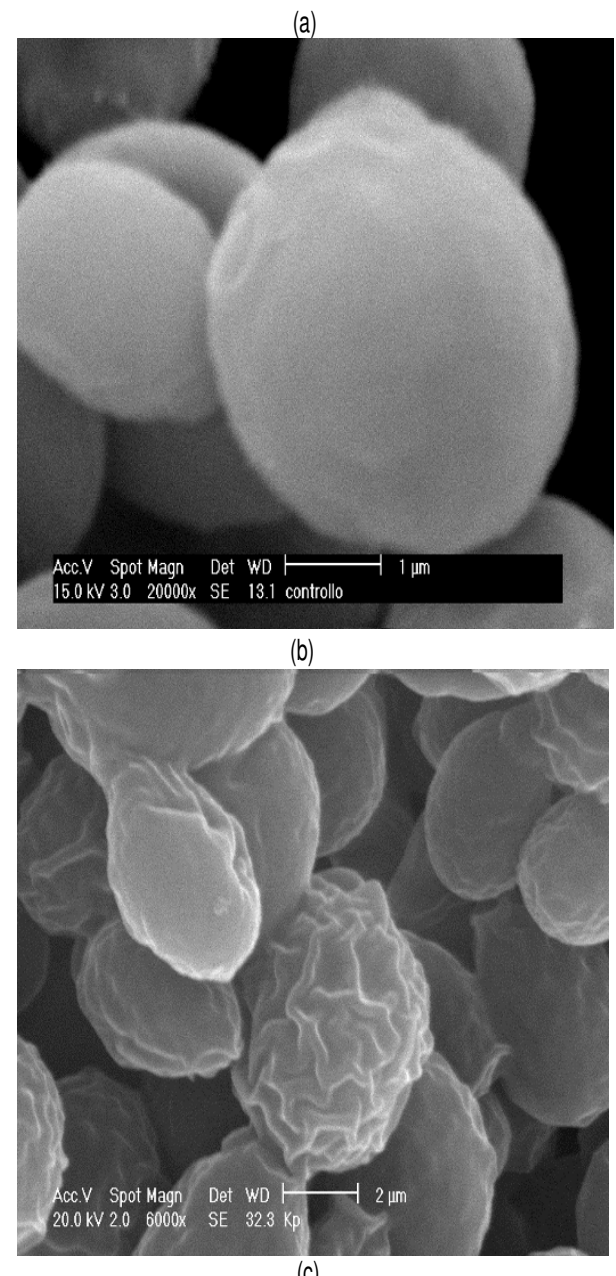

(c)

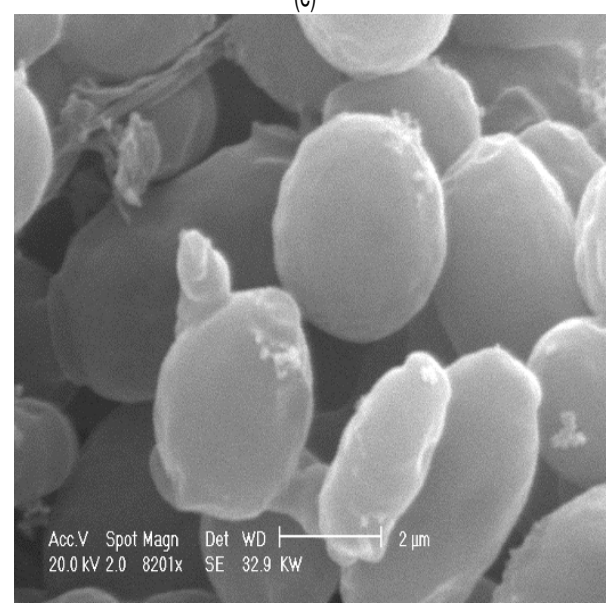

Figure 3

Scanning electron microscopy analysis of the S. cerevisiae sensitive strain. (a) Untreated cells; (b) cells treated for 24 $\mathrm{h}$ with $46 \mathrm{aU} \mathrm{Kpkt}$; and (c) cells treated for $24 \mathrm{~h}$ with $46 \mathrm{aU} \mathrm{KI}$. 
(a)

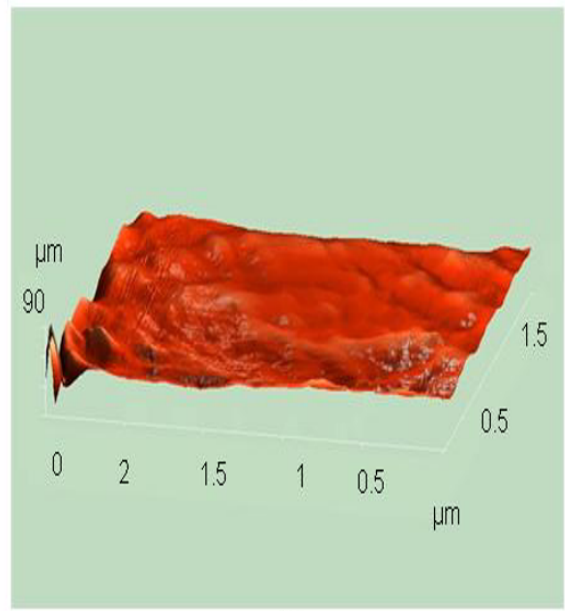

(b)

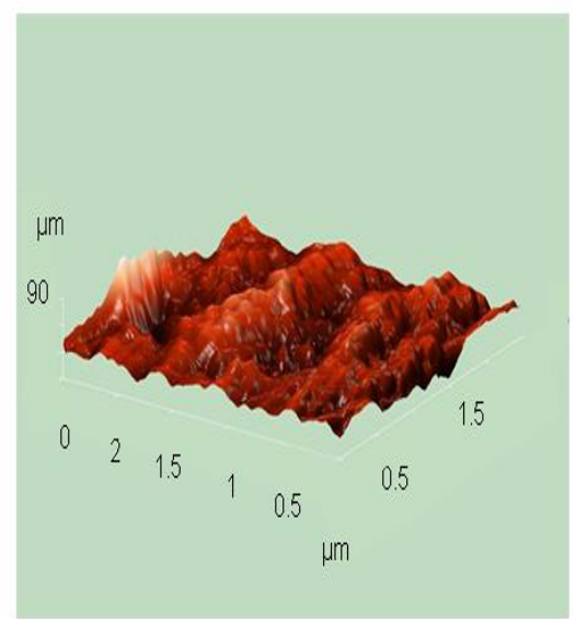

(c)

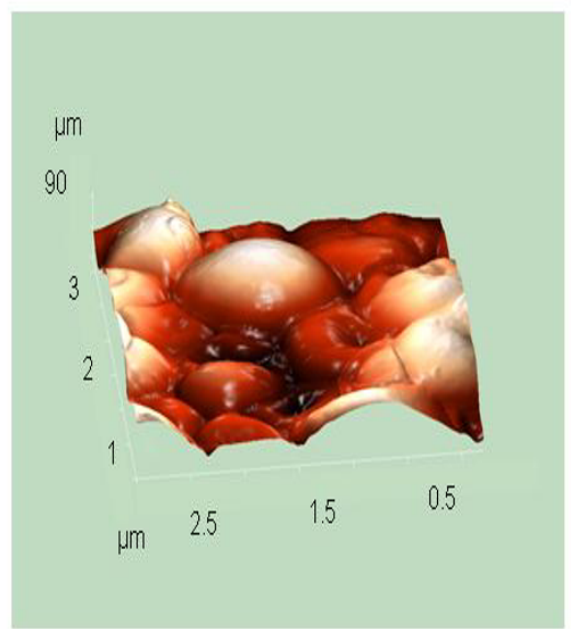

Figure 4

Scanning of the surface $\left(6.25 \mu \mathrm{m}^{2}\right)$ of $S$. cerevisiae cells by a semi-contact cantilever with AFM. (a) Untreated cells; (b) cells treated for $24 \mathrm{~h}$ with $100 \mu \mathrm{g} \mathrm{ml^{-1 }}$ purified Kpkt; and (c) cells treated for $24 \mathrm{~h}$ with $46 \mathrm{aU} \mathrm{KI}$. 
Table 4: Effects of increasing concentrations of laminarinase on Kpkt sensitive and resistant strains: comparison with Kpkt.

\begin{tabular}{|c|c|c|c|}
\hline \multirow[t]{2}{*}{ Sample } & \multirow[t]{2}{*}{ Concentration $\left(\mathrm{mg} \mathrm{ml}^{-1}\right)$} & \multicolumn{2}{|c|}{$\%$ dead cells } \\
\hline & & Kpkt-sensitive strain & $\begin{array}{l}\text { Kpkt-resistant } \\
\text { strain }\end{array}$ \\
\hline Kpkt & 0.05 & 65.4 & 5.4 \\
\hline \multirow[t]{4}{*}{ Laminarinase } & 0.05 & 1.3 & 3.5 \\
\hline & 2.5 & 15.2 & 17.2 \\
\hline & 12.5 & 40.8 & 52.7 \\
\hline & 25 & 63.7 & 78.4 \\
\hline
\end{tabular}

Percentages of dead cells was evaluated by flow cytometry after propidium iodide staining.

Kpkt has a highly specific activity and its glucidic fraction mediates its killer action

Table 4 shows the results of the treatments of two different yeast strains with Kpkt in comparison with increasing concentrations of a commercial laminarinase. Laminarinase killed Kpkt sensitive and resistant yeasts in a dose-dependent fashion. In contrast, Kpkt acted selectively on the sensitive strain, and as expected, it did not have any effects on the resistant yeast strain. Moreover, comparison between Kpkt and laminarinase showed that the cytocidal effect of commercial laminarinase is 500-fold lower than that of Kpkt. Thus, while Kpkt enzymatic activity in vitro is comparable to that of laminarinase [6], its cytocidal activity in vivo is significantly higher than that of laminarinase. Results of endoglycosidase-H killer toxin treatments, shown in Table 5, indicate that the removal of Kpkt glucidic residues results in a loss in its killer activity, demonstrating that the sugar fraction is involved in the mode of action of this killer toxin.

\section{Discussion}

Kpkt is a glycoprotein that is secreted by T. phaffii and recognizes $\beta$-1,3-and $\beta$-1,6-branched glucans as its receptor site on the cell wall of the sensitive target. The $\mathrm{NH}_{2}$-terminal amino-acid sequence of this killer toxin shares high homology with proteins belonging to the $\beta$-glucanase lytic enzyme family, and the $\beta$-glucanase activity of Kpkt has been established in vitro [6].

Previous studies have reported a broad spectrum of activity for Kpkt, and demonstrated its stability under wine- making conditions, indicating its promising features for use as a novel antiseptic agent in the wine and beverage industries $[10,18,27]$. In the present study, the mode of action Kpkt was characterized in view of its potential application as a natural antimicrobial agent.

The inhibitory effects of castanospermine on both the enzymatic and killer activities of Kpkt confirmed that $\beta$ glucanase activity mediates Kpkt killer action in vivo. On this basis, we hypothesized that Kpkt has a hydrolytic activity on $\beta$-glucans within the cell wall of sensitive yeasts. The inability of Kpkt to kill spheroplasts confirmed this hypothesis and highlighted the role of the cell wall in interactions with the toxin. Moreover, this result indicated that in contrast to the S. cerevisiae K1 and K2 killer toxins [28], Kpkt does not have any action on the plasma membrane. The disappearance of the Kpkt killer effect on whole sensitive cells in an isotonic environment indicated that the cell wall is the only target of its mode of action.

This study of the cell envelope of Kpkt-treated sensitive cells using Calcofluor White ${ }^{\circledast}$ Stain, and the SEM and AFM examinations, highlighted the specific damage produced by this toxin on the cell wall of sensitive strains. These techniques revealed that Kpkt produces a high level of roughness of the cell wall of the sensitive target, and causes changes in cell morphology. Moreover, it was seen that the cell-wall degrading activity of Kpkt is completely different to that of the S. cerevisiae K1 killer toxin, where the mechanism of action on the permeability of the cell membrane is known $[23,29]$.

Table 5: Effects of endoglycosidase-H treatment on Kpkt killer activity.

\begin{tabular}{|c|c|c|}
\hline Conditions & $\begin{array}{l}\text { After } 24 \mathrm{~h} \text { incubation } \\
\left(\mathrm{CFU} \times 10^{5} \mathrm{ml}^{-1}\right)\end{array}$ & $\begin{array}{l}\text { After } 48 \mathrm{~h} \text { incubation } \\
\left(\text { CFU } \times 10^{5} \mathrm{ml}^{-1}\right)\end{array}$ \\
\hline Without Kpkt & $17.0 \pm 1.27$ & $56.0 \pm 8.48$ \\
\hline With Kpkt & $0.5 \pm 0.14$ & $0.03 \pm 0.016$ \\
\hline With Kpkt + Endo H & $6.4 \pm 0.42$ & $6.7 \pm 0.56$ \\
\hline With Kpkt and without Endo H & $0.29 \pm 0.098$ & $0.43 \pm 0.013$ \\
\hline
\end{tabular}

The initial inoculum of sensitive cells was $2 \times 10^{5}$ cell $\mathrm{ml}^{-1}$. Data are means $\pm \mathrm{SD}$ of three experiments. 
The strict relationship between Kpkt killer and $\beta$-glucanase activities indicates that the cell wall of the sensitive strain represents the specific binding site and the target of both killer and $\beta$-glucanase activities.

The comparison of the cytocidal activity of laminarinase and Kpkt showed for Kpkt a higher specific activity toward the yeast cell target. Indeed, a concentration of Kpkt 500fold lower than that of laminarinase was sufficient to obtain a comparable killer action. Moreover, Kpkt showed a different selective action towards the yeast cell target that towards laminarinase.

\section{Conclusion}

In conclusion, these data indicate that the mode of action of Kpkt is directed toward the cell wall, and that it is different from that of a commercial $\beta$-glucanase such as laminarinase. Both high specific cytocidal activity and selectivity of Kpkt differentiate the $\beta$-glucanase of T. phaffii from other microbial $\beta$-glucanases that do not show killer action and might have biotechnological applications [30,31]. In addition, our data indicate that the glucidic portion of Kpkt has an important role in its killer action. We therefore hypothesize that both the selectivity and specific activity of Kpkt depend on the glucidic fraction of the toxin.

\section{Competing interests}

The authors declare that they have no competing interests.

\section{Authors' contributions}

FC, IM and MC contributed equally to this manuscript. FC performed the experimental part of the work. FC, IM and $\mathrm{MC}$ carried out the analysis of the data and wrote the manuscript. All authors participated in the design and discussion of the research. MC directed the research. All the authors have read and approved the final manuscript.

\section{Acknowledgements}

F Comitini was partially supported by a grant from the Università Politecnica delle Marche. The authors are grateful to A Di Donato and L Maccari for their valuable help with the AFM experiments.

\section{References}

I. Schmitt MJ, Breinig F: The viral killer system in yeast: from molecular biology to application. FEMS Microbiol Rev 2002, 26:257-276.

2. Wickner RB: Double-stranded and single-stranded RNA viruses of Saccharomyces cerevisiae. Ann Rev Microbiol 1992, 46:347-375.

3. Wickner RB: Double-stranded RNA viruses of Saccharomyces cerevisiae. Microbiol Rev 1996, 60:250-265.

4. Kagan BL: Mode of action of yeast killer toxins: channel formation in lipid bilayer membranes. Nature 1983, 302:709-7। I.

5. Takasuka T, Komiyama T, Furuichi $Y$, Watanabe T: Cell-wall-synthesis-specific cytocidal effect of Hansenula mrakii toxin-I on Saccharomyces cerevisiae. Cell Mol Biol Res 1995, 41:575-58I.

6. Comitini F, Di Pietro N, Zacchi L, Mannazzu I, Ciani M: Kluyveromyces phaffii killer toxin active against wine spoilage yeasts: purification and characterization. Microbiology 2004, I50:2535-254l.

7. Izgü $F$, Altinbay $D$, Türeli $A E$ : In vitro activity ofpanomycocin, a novel exo-beta-I,3-glucanase isolated from Pichia anomala NCYC 434, against dermatophytes. Mycoses 2007, 50:3I-34.

8. Wang $X, C h i$, Yue L, Li J: Purification and characterization of killer toxin from a marine yeast Pichia anomala YF07b against the pathogenic yeast in crab. Curr Microbiol 2007, 55:396-40I.

9. Boone C, Sommer SS, Hensel A, Bussey H: Yeast KRE genes provide evidence for a pathway of cell wall beta-glucan assembly. J Cell Biol 1990, I 1 0: 1833-1843.

10. Palpacelli V, Ciani M, Rosini G: Activity of different killer yeasts on strains of yeast species undesirable in the food industry. FEMS Microbiol Lett 1991, 84:75-78.

II. van Vuuren $\mathrm{HJJ}$, Jacobs CJ: Killer yeasts in the wine industry: a review. Am. J. Enol. Vitic. 1992, 2:1 I9-I28.

12. Hodgson VJ, Button D, Walker GM: Anti-Candida activity of a novel killer toxin from the yeast Williopsis mrakii. Microbiology 1995, 141:2003-2012.

13. Seguy N, Polonelli L, Dei-Cas E, Cailliez JC: Effect of a killer toxin of Pichia anomala to Pneumocystis. Perspectives in the control of pneumocystosis. FEMS Immunol Med Microbiol 1998, 22:145-149.

14. Boekhout T, Scorzetti G: Differential killer toxin sensitivity patterns of varieties of Cryptococcus neoformans. J Med Vet Mycol 1997, 35: I47-149.

15. Buzzini P, Martini A: Large-scale screening of selected Candida maltosa, Debaryomyces hansenii and Pichia anomala killer toxin activity against pathogenic yeasts. Med Mycol 200I, 39:479-482.

16. Morace G, Manzara S, Dettori G, Fanti F, Conti S, Campani L, Polonelli $L$, Chezzi C: Biotyping of bacterial isolates using the yeast killer system. Eur J Epidemiol 1989, 5:303-310.

17. Ueda-Nishimura K, Mikata K: A new yeast genus, Tetrapisispora gen. nov.: Tetrapisispora iriomotensis sp. nov., Tetrapisispora nanseiensis sp. nov. and Tetrapisispora arboricola sp. nov., from the Nansei Islands, and reclassification of Kluyveromyces phaffii (van der Walt) van der Walt as Tetrapisispora phaffii comb. nov. Int J Syst Bacteriol 1999, 49:1915-1924.

18. Ciani M, Fatichenti F: Killer toxin of Kluyveromyces phaffii DBVPG 6076 as a biopreservative agent to control apiculate wine yeasts. Appl Environ Microbiol 200I, 67:3058-3063.

19. Goldman RC, Sullivan PA, Zakula D, Capobianco JO: Kinetics of beta-I,3-glucan interaction at the donor and acceptor sites of the fungal glucosyltransferase encoded by BGL2 gene. Eur J Biochem 1995, 227:372-378.

20. Mrsã V, Klebl F, Tanner W: Purification and characterization of the Saccharomyces cerevisiae BGL2 gene product, a cell wall endo- $\beta$ - I,3-glucanase. J Bacteriol 1993, 175:2 102-2106.

21 . Izgü $F$, Altinbay $D$ : Isolation and characterization of the K5type yeast killer protein and its homology with an exo-betaI,3-glucanase. Biosci Biotechnol Biochem 2004, 68:685-693.

22. Komiyama T, Kimura T, Furuichi $Y$ : Round shape enlargement of the yeast spheroplast of Saccharomyces cerevisiae by HM-I toxin. Biol Pharm Bull 2002, 25:959-965.

23. Elgersma $Y$, Kwast L, Berg M van den, Snyder WB, Distel B, Subramani $S$, Tabak HF: Overexpression of Pex I5p, a phosphorylated peroxisomal integral membrane protein required for peroxisome assembly in $S$. cerevisiae, causes proliferation of the endoplasmic reticulum membrane. EMBO J 1997:7326-734I.

24. Green L, Petersen B, Steimel L, Haeber P, Current W: Rapid determination of antifungal activity by flow cytometry. J Clin Microbiol 1994, 32: 1088-1091.

25. Pereira RS: Atomic force microscopy as a novel pharmacological tool. Biochem Pharmacol 2001, 62:975-983.

26. Pereira RS, Duràn $\mathrm{H}$, Teschke O: Observation of structures on Saccharomyces cerevisiae cell wall by atomic force microscope. Probe Microsc 1998, I:277-282.

27. Rosini G, Cantini M: Killer character in Kluyveromyces yeasts: activity on Kloeckera apiculata. FEMS Microbiol Lett 1987, 44:8I-84.

28. Novotná D, Flegelová $H$, Janderová B: Different action of killer toxin $\mathrm{KI}$ and $\mathrm{K} 2$ on the plasma membrane and the cell wall of Saccharomyces cerevisiae. FEMS Yeast Res 2004, 4:803-8I3. 
29. Ahmed A, Sesti F, llan N, Shih TM, Sturley LS, Goldstein SA: A molecular target for viral killer toxin: TOKI potassium channels. Cell 1999, 99:283-29I.

30. Peng Y, Chi ZM, Wang XH, Li J: Purification and molecular characterization of exo-beta-I,3-glucanases from the marine yeast Williopsis saturnus WC9I-2. Appl Microbiol Biotechnol 2009, 85:85-94.

31. Ferrer P: Revisiting the Cellulosimicrobium cellulans yeast-lytic beta-I,3-glucanases toolbox: a review. Microb Cell Fact 2006, 5: $10-15$.

Publish with Biomed Central and every scientist can read your work free of charge

"BioMed Central will be the most significant development for disseminating the results of biomedical research in our lifetime. " Sir Paul Nurse, Cancer Research UK

Your research papers will be:

- available free of charge to the entire biomedical community

- peer reviewed and published immediately upon acceptance

- cited in PubMed and archived on PubMed Central

- yours - you keep the copyright 